\title{
Hyperthermotherapy in the Rice Emasculation Process
}

\author{
Gabriel Almeida Aguiar ${ }^{1 *}$, Eduardo Anibele Streck ${ }^{1}$, \\ Paulo Henrique Karling Facchinello', Carolina Goulart', \\ Ariano Martins de Magalhães Junior ${ }^{2}$ and Luciano Carlos da Maia ${ }^{1}$ \\ ${ }^{1}$ Departamento de Fitotecnia, Faculdade de Agronomia Eliseu Maciel, Universidade Federal \\ de Pelotas, Pelotas, Brasil. \\ ${ }^{2}$ Embrapa Clima Temperado, Pelotas, Brasil.
}

Authors' contributions

This work was carried out in collaboration between all authors. Authors GAA and AMMJ designed the study and performed the statistical analysis. Author GAA wrote the protocol and wrote the first draft of

the manuscript. Authors AMMJ and LCM managed the analyses of the study. Author CG managed

the literature searches. Authors EAS and PHKF performed the experiments, participated in fieldwork and laboratory analysis. All authors read and approved the final manuscript.

Article Information

DOI: $10.9734 / J E A I / 2017 / 37597$

Editor(s):

(1) Aleksander Lisowski, Department Agricultural and Forestry Engineering, Warsaw University of Life Sciences, Poland.

(1) Elena Rakosy-Tican, Babes-Bolyai University, Romania. (2) Boryana Dyulgerova, Institute of Agriculture-Karnobat, Bulgaria. Complete Peer review History: http://www.sciencedomain.org/review-history/21784

Original Research Article

Received $21^{\text {st }}$ October 2017 Accepted $2^{\text {nd }}$ November 2017 Published $7^{\text {th }}$ November 2017

\section{ABSTRACT}

Aims: The objective of this work was to evaluate the emasculation by hyperthermotherapy method in irrigated rice genotypes, and to compare it with the emasculation by vacuum suction.

Study Design: The experimental design used to compare the two methods was completely randomized, with two treatments (emasculation by hyperthermotherapy and vacuum suction) and six replications. To analyze the emasculation by hyperthermotherapy, this design was also used with three replications.

Place and Duration of Study: The study was carried out in the agricultural years of 2012/2013 (1st year) and 2013/2014 (2nd year), at the Terras Baixas Experimental Station of Embrapa Clima Temperado, in the municipality of Capão do Leão, RS (31⒋'15.47" S and 5224'47.11" W). 
Methods: In the emasculation by hyperthermotherapy, 48 treatments were analyzed, consisting of the combination of 6 water temperatures $\left(40^{\circ} \mathrm{C}, 42^{\circ} \mathrm{C}, 4^{\circ} \mathrm{C}, 4^{\circ} \mathrm{C}, 48^{\circ} \mathrm{C}\right.$ and $\left.50^{\circ} \mathrm{C}\right), 4$ panicle immersion times (2.5 min, $5.0 \mathrm{~min}, 7.5 \mathrm{~min}$ and $10 \mathrm{~min}$ ) and two cultivars (BRS Pampa and IAS 12-9 Formosa).

Results: The progressive increase in the temperature and time decreases the formation of grains until a certain condition in which the total sterilization of rice flowers occurs, being possible execute the emasculate before this occurs. This condition is $46^{\circ} \mathrm{C}$ for 2.5 minutes of panicle immersion. The genotype IAS 12-9 Formosa showed higher tolerance to high temperatures.

Conclusion: The condition that presented the best result to perform the hybridization was a temperature of $46^{\circ} \mathrm{C}$ for a panicle immersion time of 2.5 minutes for both cultivars. The hyperthermotherapy produces a smaller amount of grains, but presents a lower percentage of selffertilization, thus, being more effective in the artificial rice hybridization process.

Keywords: Oryza sativa; genetic enhancement; crossing; hybridization.

\section{INTRODUCTION}

Among the several stages of a rice-breeding program, hybridization is one of the most important and fundamental, since it allows associating characteristics manifested in other genotypes in a single genotype. Through this process, genes are transferred between plants, increasing the genetic variability and increasing the possibility of forming new genetic combinations, among these some can be highly favorable, leading to agronomically superior genotypes.

In rice, the emasculation technique normally used in breeding programs consists of cutting the top of the spikelets and removing the anthers by means of a vacuum pump. However, this method is laborious, has low operating efficiency, and needs skilled labor to remove the anthers in order to prevent contact with the suction tip that can cause mechanical damage to the stigma [1, 2].

An alternative method is hyperthermotherapy, which consists in the use of a particular source of heat, in this specific case hot water, to promote the increase of the temperature of the floral structure. This method is based on the difference in thermal sensitivity between the male and female part of the rice flower, where pollen grains are more sensitive to higher temperatures than stigma. The male gametophyte is particularly sensitive to high temperatures at all stages of development, whereas the pistil and the female gametophyte are considered more tolerant [3]. Hyperthermotherapy is easy to perform, less labor intensive, and does not necessarily require skilled labor [4].

As rice breeding programs perform numerous hybridizations in order to introduce new genes into their working germplasm and/or hybridizations among their elite genotypes to develop their cultivars, there is a need to refine emasculation methods to provide greater benefits at this stage of the program.

Analyzing the need to create new emasculation methodologies, which are practical, inexpensive and have high yields to facilitate this step in breeding programs, the present study aims to evaluate the method of emasculation by hyperthermotherapy in genotypes of irrigated rice (Oryza sativa L.), of the Indica and Japonica subspecies, and to compare it with the vacuum suction method.

\section{MATERIALS AND METHODS}

The study was carried out in the agricultural years of 2012/2013 (1st year) and 2013/2014 (2nd year), at the Terras Baixas Experimental Station of Embrapa Clima Temperado, in the municipality of Capão do Leão, RS (31'48'15.47" $S$ and 5224'47.11" W). In the first year of the experiment, only the emasculation process was carried out, with all studied treatments, in order to determine the viability of the pollen grain (Table 1). In the 2nd year, the emasculation was performed with the treatments that could provide the sterility of the pollen grain without causing thermal damage in the female part of the flower. These were treatments that presented results close to zero, and referred to treatments with the temperatures of $46^{\circ} \mathrm{C}, 48^{\circ} \mathrm{C}$ and $5^{\circ} \mathrm{C}$, in the four analyzed times. Later, artificial pollination was carried out.

Three rice genotypes (Oryza sativa L.) were used, two to evaluate the process of emasculation by hyperthermotherapy, the BRS Pampa (Indica subspecies), IAS 12-9 Formosa (Japanica subspecies) and the third was BRS 
Querência (Indica subspecies), being used as male parent in hybridization. The sowing was done in a staggered way, to coincide with the flowering of the cultivars, in 10-liter buckets filled with soil classified as Albaqualf soil.

Table 1. Treatments performed in the hyperthermotherapy emasculation process in rice cultivars BRS Pampa and IAS 12-9 Formosa

\begin{tabular}{|c|c|c|c|c|c|}
\hline \multirow[t]{2}{*}{ Treat. } & \multicolumn{2}{|c|}{ BRS Pampa } & \multirow[t]{2}{*}{ Treat. } & \multicolumn{2}{|c|}{$\begin{array}{l}\text { IAS 12-9 } \\
\text { formosa }\end{array}$} \\
\hline & $\begin{array}{l}\text { Temp. } \\
\text { (C) }\end{array}$ & $\begin{array}{l}\text { Time } \\
\text { (min) }\end{array}$ & & $\begin{array}{l}\text { Temp. } \\
\text { (C) }\end{array}$ & $\begin{array}{l}\text { Time } \\
\text { (min) }\end{array}$ \\
\hline T1 & 40 & 2.5 & T25 & 40 & 2.5 \\
\hline T2 & 40 & 5.0 & T26 & 40 & 5.0 \\
\hline T3 & 40 & 7.5 & T27 & 40 & 7.5 \\
\hline T4 & 40 & 10.0 & T28 & 40 & 10.0 \\
\hline T5 & 42 & 2.5 & T29 & 42 & 2.5 \\
\hline T6 & 42 & 5.0 & T30 & 42 & 5.0 \\
\hline T7 & 42 & 7.5 & T31 & 42 & 7.5 \\
\hline T8 & 42 & 10.0 & T32 & 42 & 10.0 \\
\hline T9 & 44 & 2.5 & T33 & 44 & 2.5 \\
\hline T10 & 44 & 5.0 & T34 & 44 & 5.0 \\
\hline $\mathrm{T} 11$ & 44 & 7.5 & T35 & 44 & 7.5 \\
\hline $\mathrm{T} 12$ & 44 & 10.0 & T36 & 44 & 10.0 \\
\hline T13 & 46 & 2.5 & T37 & 46 & 2.5 \\
\hline $\mathrm{T} 14$ & 46 & 5.0 & T38 & 46 & 5.0 \\
\hline $\mathrm{T} 15$ & 46 & 7.5 & T39 & 46 & 7.5 \\
\hline $\mathrm{T} 16$ & 46 & 10.0 & $\mathrm{~T} 40$ & 46 & 10.0 \\
\hline $\mathrm{T} 17$ & 48 & 2.5 & T41 & 48 & 2.5 \\
\hline T18 & 48 & 5.0 & T42 & 48 & 5.0 \\
\hline T19 & 48 & 7.5 & T43 & 48 & 7.5 \\
\hline T20 & 48 & 10.0 & T44 & 48 & 10.0 \\
\hline T21 & 50 & 2.5 & T45 & 50 & 2.5 \\
\hline T22 & 50 & 5.0 & T46 & 50 & 5.0 \\
\hline T23 & 50 & 7.5 & T47 & 50 & 7.5 \\
\hline T24 & 50 & 10.0 & $\mathrm{~T} 48$ & 50 & 10.0 \\
\hline
\end{tabular}

The emasculation process was performed when the panicle was in the reproductive stage $\mathrm{R} 2$ R3, and the spikelets were removed from the upper third (self-fertilized) and lower third (immature), resulting between 50 and 60 spikelets per panicle, with each spikelet cut on top with scissors before being immersed in the "water bath". After, the panicles were identified and protected until the grain maturation.

The pollination stage performed in the 2nd year, was shortly after the emasculation, placing in the envelope a panicle of the male parent along with one of the female parent and in the period from 12:00 to $13: 30 \mathrm{~h}$, when the spikelets had their anthers and stigma exposed, by manually shaking the envelope so that the pollen "rain" of occurred.
Four weeks after emasculation, the number of fertile and sterile spikelets was determined in order to determine the ideal emasculation conditions. The spikelets that formed the grain indicate that the treatment was not able to carry out the sterilization of the pollen grains, leading to self-fertilization. In the 2nd year, after four weeks of pollination, the percentage of sterile and formed grains was calculated, thus observing the occurrence or not of artificial hybridization, and thus verifying the viability of the female structure.

To compare the emasculation by hyperthermotherapy with vacuum suction methods, the experiment was carried out in two agricultural years. The first one in 2012/2013 in a greenhouse, to carry out the hybridizations with the two methods of emasculation and in the second agricultural year in 2013/2014, the seeds from each method were seeded in the experimental field, in order to determine the number of self-fertilized plants and hybrids. Emasculation by hyperthermotherapy was performed at a water temperature of $45^{\circ} \mathrm{C}$ for a panicle immersion time of 5 minutes In both emasculation methods, the BRS Querência was used as the female parent and BRS Pampa as the male one.

In the 1st year, after 30 days of pollination, the number of grains formed was assessed by counting, and the percentage for the emasculation methods analyzed was calculated. In the 2nd year, for each method, the number of self-fertilized and hybrid plants was determined through a morphological marker of hairiness, with glabrous plants resulting from self-pollination and pilose ones from artificial hybridization.

The experimental design used to compare the two methods was completely randomized, with two treatments (emasculation by hyperthermotherapy and vacuum suction) and six replications. To analyze the emasculation by hyperthermotherapy, this design was also used with three replications. Data were submitted to analysis of variance (ANOVA) through the statistical program Assistat, version 7.6 [5].

\section{RESULTS AND DISCUSSION}

With a time of $2.5 \mathrm{~min}$ and temperature of $40^{\circ} \mathrm{C}$, the cultivars IAS 12-9 Formosa and BRS Pampa presented a grain formation of $39.47 \%$ and $41.20 \%$, respectively, being in group "d" and statistically differing from the other three panicle 
immersion times in the "e" group (Table 2). Thus, it can be inferred that at the temperature of $40^{\circ} \mathrm{C}$ independently of the analyzed times, the percentage of grains formed was high for the process (Fig. 1A), not being an efficient treatment for rice emasculation.

At $42^{\circ} \mathrm{C}$ (Fig. 1B), BRS Pampa cultivar showed a gradual reduction in the percentage of grains formed as the panicle immersion time increased, where at the initial time the percentage of grains formed was $47.48 \%$ (group e) and at the final time, this was $16.63 \%$ (group b) according to Table 2. For IAS 12-9 Formosa, the grain formation was $39.02 \%$ (group d) at time 2.5 minutes, with an increase in self-fertilization (\% of grains formed) at the time of 5 minutes $(51.61 \%)$, remaining statistically the same at 7.5 minutes and 10 minutes, where the percentage of grains formed was $47.93 \%$ and $45.93 \%$, respectively (Table 2). In this way, it can be inferred that the cultivar IAS 12-9 Formosa has a higher tolerance than the BRS Pampa at this temperature during the flowering period, because with the increase of the panicle immersion time at that temperature, there was no reduction in the formation of grains.

At a temperature of $4^{\circ} \mathrm{C}$ (Fig. $1 \mathrm{C}$ ), it was observed that the variation in the percentage of grains formed in the Japonica subspecies genotype was lower, with $37.02 \%$ (group d) at the time of 2.5 minutes and after 10 minutes, this was $16.65 \%$ (group b), presenting a high level of viability of pollen grain with increasing emasculation time at this temperature (Table 2). The variation in the percentage of grains formed in the Indica subspecies genotype was higher, with an increase in the panicle immersion time from 2.5 to 5 minutes, with a variation from $48.69 \%$ to $4.56 \%$, remaining statistically the same at all times, thus demonstrating that this genotype is less tolerant to high temperatures than the Japonica subspecies genotype.

In Fig. 1D, it is observed that during all the evaluated times, cultivar IAS 12-9 Formosa showed a higher percentage of grains formed than BRS Pampa, showing a reduction from $10.71 \%$ (group b) to $2.66 \%$ (group a) as the panicle immersion time increased (Table 2).

It can be seen in Fig. 1E that the two cultivars presented some similarity, and the percentage of grains formed from IAS 12-9 Formosa $(3.60 \%)$ was slightly higher than BRS Pampa $(2.92 \%)$ at time 2.5 minutes, but not statistically different from each other nor from times $5,7.5$ and 10 minutes, where the genotypes had the same percentage of grains formed, showing a desired hyperthermotherapeutic emasculation (Table 2).

At $50^{\circ} \mathrm{C}$ (Fig. 1F), it can be seen that for the two cultivars analyzed, the first panicle immersion time was able to provide a desired emasculation, remaining statistically the same for the other analyzed times (Table 2).

According to the results, it is observed that the temperature is an important factor in the determination of grain formation in rice. The development stage in which the plant is exposed to high temperatures determines the severity of possible grain formation damage. Temperatures higher than the ideal in the reproductive phase induce the sterility of the spikelets and consequently decrease the productivity [6]. In rice, the period of microsporogenesis and flowering are considered the most sensitive stages at high temperatures [7].

Table 2. Percentage of grains formed after emasculation by hyperthermotherapy in rice cultivars BRS Pampa and IAS 12-9 Formosa

\begin{tabular}{|c|c|c|c|c|c|c|c|c|}
\hline \multirow{3}{*}{$\begin{array}{l}\text { Temp. } \\
\text { ('C) }\end{array}$} & \multirow{2}{*}{\multicolumn{4}{|c|}{$\begin{array}{c}\text { BRS Pampa } \\
\text { Time (min) }\end{array}$}} & \multirow{2}{*}{\multicolumn{4}{|c|}{$\begin{array}{c}\text { IAS 12-9 Formosa } \\
\text { Time }(\min )\end{array}$}} \\
\hline & & & & & & & & \\
\hline & 2.5 & 5 & 7.5 & 10 & 2.5 & 5 & 7.5 & 10 \\
\hline 40 & $41.20 \mathrm{~dB}$ & $47.67 \mathrm{eD}$ & $46.91 \mathrm{eC}$ & $45.47 \mathrm{eC}$ & $39.47 \mathrm{~dB}$ & $53.72 \mathrm{eD}$ & $52.06 \mathrm{eC}$ & $48.02 \mathrm{eC}$ \\
\hline 42 & $47.48 \mathrm{eB}$ & $34.83 \mathrm{dC}$ & $27.83 c B$ & $16.63 \mathrm{bB}$ & $39.02 \mathrm{~dB}$ & $51.61 \mathrm{eD}$ & $47.93 \mathrm{eC}$ & $45.93 e C$ \\
\hline 44 & $48.69 \mathrm{eB}$ & $4.56 \mathrm{aB}$ & $2.42 \mathrm{aA}$ & $2.29 \mathrm{aA}$ & $37.02 \mathrm{~dB}$ & $30.09 c C$ & $29.57 \mathrm{cB}$ & $16.65 \mathrm{bB}$ \\
\hline 46 & $3.01 \mathrm{aA}$ & $1.62 \mathrm{aA}$ & $1.89 \mathrm{aA}$ & $1.04 \mathrm{aA}$ & $10.71 b A$ & $8.66 \mathrm{bB}$ & $3.41 \mathrm{aA}$ & $2.66 a A$ \\
\hline 48 & $2.92 \mathrm{aA}$ & $0 a A$ & $0 a A$ & $0 a A$ & $3.60 \mathrm{aA}$ & $0 a A$ & $0 a A$ & $0 a A$ \\
\hline 50 & $0 \mathrm{aA}$ & $0 a A$ & $0 \mathrm{aA}$ & $0 a A$ & $0 \mathrm{aA}$ & $0 \mathrm{aA}$ & $0 \mathrm{aA}$ & $0 \mathrm{aA}$ \\
\hline
\end{tabular}



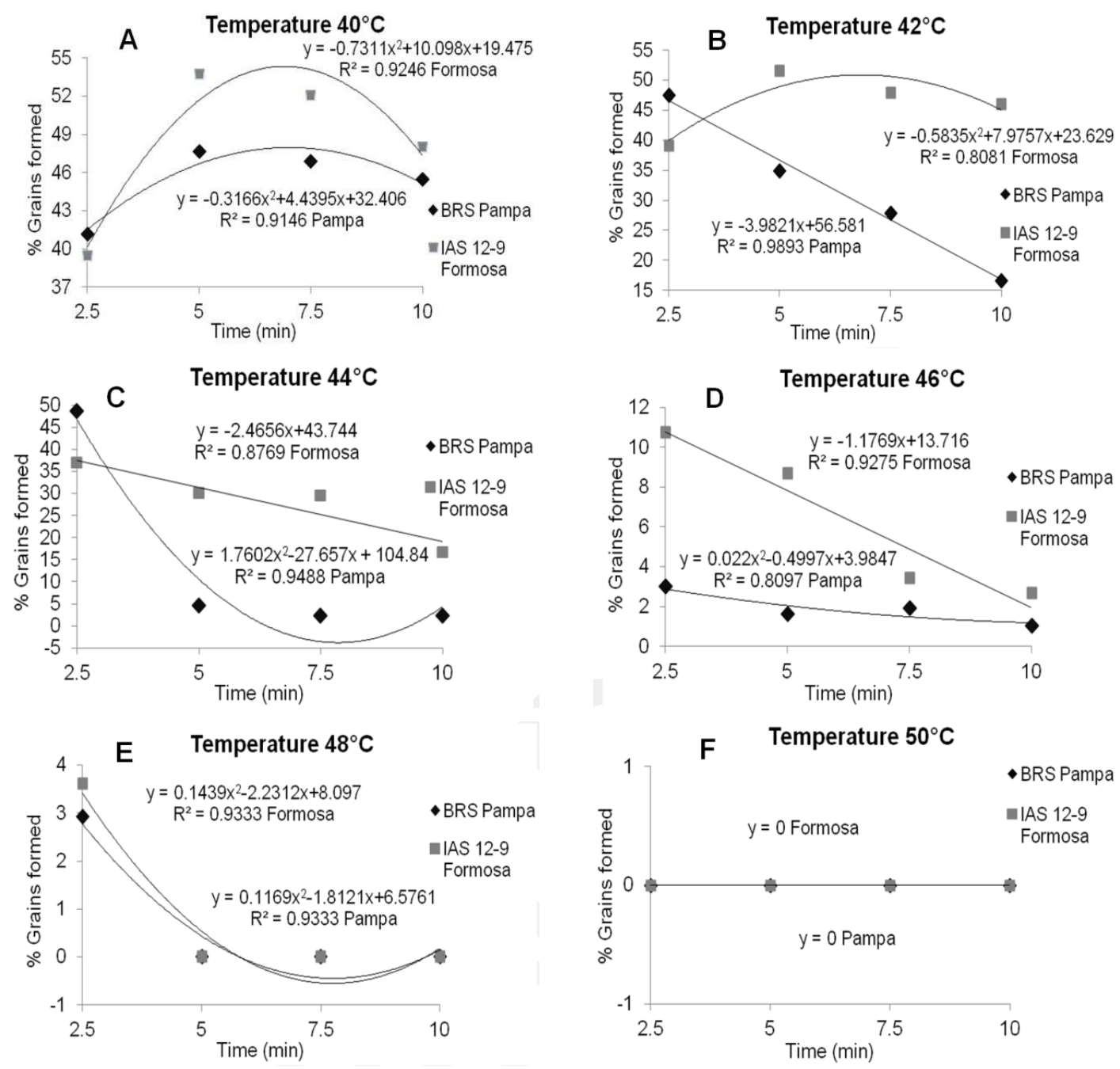

Fig. 1. Percentage of grains formed in BRS Pampa and IAS 12-9 Formosa cultivars, setting the emasculation temperatures by hyperthermotherapy

There is a genotypic variability for partial tolerance to the sterility of rice spikelets at high temperatures in the Indica and Japonica subspecies of Oryza sativa [8]. Different characteristics are mentioned among tolerant or susceptible genotypes, the occurrence of well-developed locular cavities in the anthers and thick walls allow easy rupture of the septa in response to increased pollen grain volume resulting in better anther dehiscence and pollination in tolerant cultivars [9].

Some morphological characteristics may be related to the high temperature tolerance in the reproductive phase of rice. If the plant architecture presents itself in such a way that the panicle is surrounded by many leaves, it will be able to withstand the high temperatures, due to the increase in the cooling in the perspiration, preventing the evaporation in the anther, due to the shading provided by the leaves, thus guaranteeing pollen grains swelling and anther dehiscence [10]. Genotypes with greater anther length are more tolerant to high temperatures since they have a large number of pollen grains per anther, which compensates for their germination in the stigma [11].

According to the results obtained in the process of emasculation by hyperthermotherapy, it was observed that IAS-12 Formosa cultivar, belonging to the Japonica subspecies, presented a higher tolerance in the conditions under study, 
probably due to some already reported characteristics.

In Fig. 2A, it is observed that BRS Pampa and IAS 12-9 Formosa did not suffer damage in the viability of the pollen grain due to water temperature elevation from $40{ }^{\circ} \mathrm{C}$ to $44^{\circ} \mathrm{C}$ since the percentage of grains formed did not differ statistically. This proves that at a maximum period of 2.5 minutes between these temperatures, the percentage of grains formed is not affected, and emasculation can thus occur. At the temperature of $46^{\circ} \mathrm{C}$, there was a considerable reduction in the percentage of grains formed in relation to the initial temperatures in both cultivars, from $48.69 \%$ (group b) to $3.01 \%$ (group a) for BRS Pampa and $37.02 \%$ (group b) to $10.71 \%$ (group a) for IAS 12-9 Formosa. In this sense, it can be inferred that the temperature of $46^{\circ} \mathrm{C}$ during 2.5 minutes caused a significant decrease in the percentage of grains formed, remaining statistically the same with the temperatures of $48^{\circ} \mathrm{C}$ and $50^{\circ} \mathrm{C}$ (Table 2).

Fig. 2B shows a significant reduction in the percentage of grains formed in BRS Pampa, with
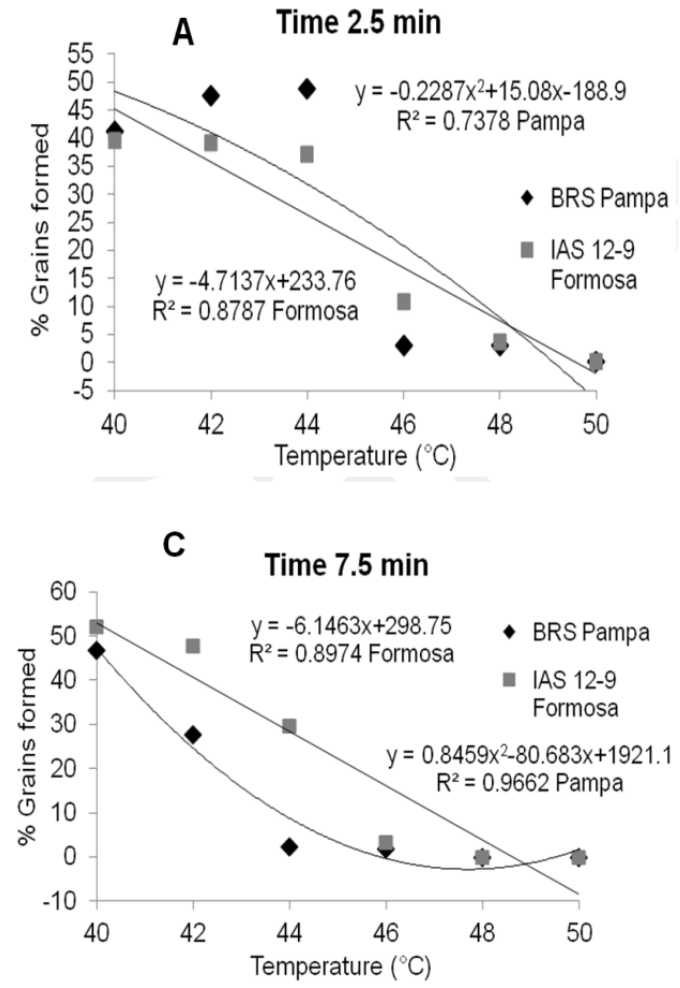

a difference in the analyzed variable between cultivars at temperatures of $42{ }^{\circ} \mathrm{C}, 44^{\circ} \mathrm{C}$ and $4^{\circ} \mathrm{C}$, where IAS 12-9 Formosa presented a higher percentage of grains formed and did not differ statistically at temperatures of $48^{\circ} \mathrm{C}$ and $50^{\circ} \mathrm{C}$ (Table 2).

During the treatment time of 7.5 minutes (Fig. $2 \mathrm{C}$ ), an abrupt reduction in grain formation is observed in BRS Pampa, with an increase in temperature from $42^{\circ} \mathrm{C}$ to $44^{\circ} \mathrm{C}$, different from IAS 12-9 Formosa, where this change occurred from $44^{\circ} \mathrm{C}$ to $46^{\circ} \mathrm{C}$, demonstrating a higher tolerance of high temperatures. However, at temperatures of $400^{\circ} \mathrm{C}, 48^{\circ} \mathrm{C}$ and $50{ }^{\circ} \mathrm{C}$ there was no statistical difference between the cultivars (Table 2).

In the treatment time of 10 minutes (Fig. 2D), a greater reduction is observed in the percentage of grains formed in the BRS Pampa than in IAS 12-9 Formosa as the emasculation temperature increases, until the two are equal, as verified at the emasculation time of 7.5 minutes (Fig. 2C). There was, nevertheless, a statistical difference between the cultivars at temperatures of $42{ }^{\circ} \mathrm{C}$ and $44^{\circ} \mathrm{C}$ (Table 2 ).
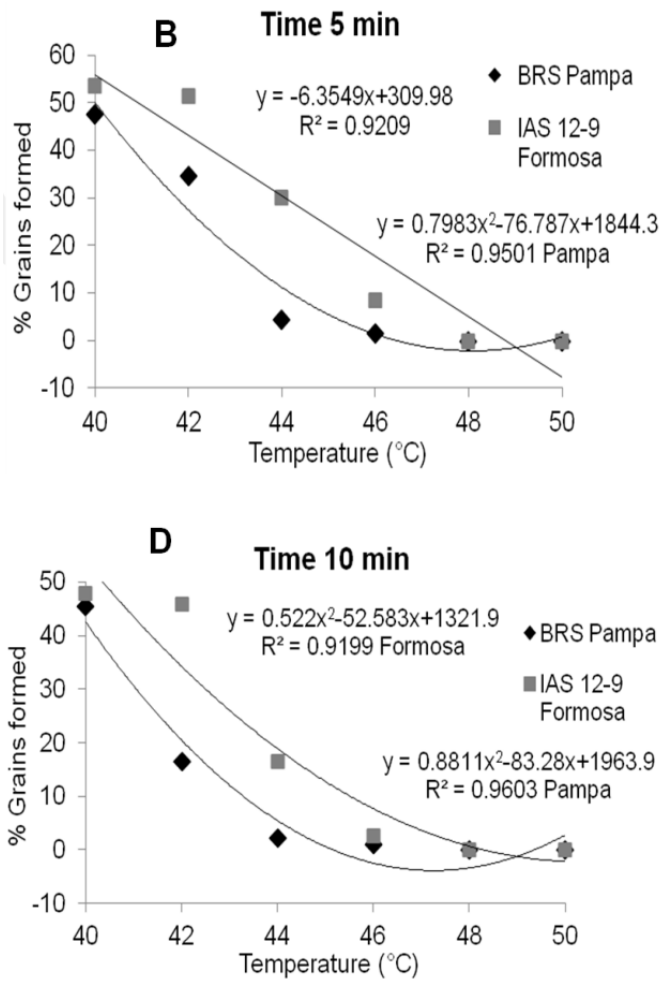

Fig. 2. Percentage of grains formed in BRS Pampa and IAS 12-9 Formosa cultivars, setting the immersion times of the rice panicle in the emasculation by hyperthermotherapy 
In emasculation by hyperthermotherapy, time is a relevant factor to determine the efficiency of the process. For example, if at a certain temperature one obtains ideal emasculation at different times, the shorter time must be used as this will result in a higher operating yield and cause less stress to the female parent.

In Cambodia rice cultivars, thermal emasculation can be applied for artificial hybridization between the Indica and Japonica genotype groups under the conditions of $43^{\circ} \mathrm{C}$ for 7 minutes [4]. Even though the present work has similar temperatures and emasculation time to the experiments of these aforementioned authors, the results are different because a higher percentage of grains was obtained.

The treatment of rice with hot water at $40^{\circ} \mathrm{C}$ to $4^{\circ} \mathrm{C}$, for $10 \mathrm{~min}$, at most, is enough to start the emasculation, and this variation depends on the genotype [12]. In the described results, there was a difference between the analyzed cultivars, with BRS Pampa presenting results that were closer to those of the authors mentioned. The ideal conditions for emasculation in rice are $4^{\circ} \mathrm{C}$ during 5 minutes so that the pollen grain loses viability and the stigma remains normal [13]. [4] reported similar efficacy in emasculation at temperatures of $45^{\circ} \mathrm{C}$ and $46^{\circ} \mathrm{C}$. The emasculation with hot water at $47^{\circ} \mathrm{C}$ is lethal to the female part of the rice flower, affecting the hybridization process [14]. Although there was no such temperature, two higher temperatures (48 ${ }^{\circ} \mathrm{C}$ and $5^{\circ} \mathrm{C}$ ) were analyzed, where this finding was confirmed in the second year of the experiment after emasculation followed by pollination.

The BRS Pampa cultivar presented $23.71 \%$ of grains formed, after the emasculation by hyperthermotherapy at the temperature of $46^{\circ} \mathrm{C}$ and time of 2.5 minutes, whereas the IAS 12-9 Formosa in this same condition presented $14.96 \%$ of grains formed (Table 3 ). Comparing these results with those of the first year of evaluation (Table 2), the two cultivars showed a higher percentage of grains formed in the second year, meaning that there was a percentage of artificial hybridization, being more expressive in BRS Pampa. This difference is explained by the lower percentage of hybridization between rice genotypes of the Indica $x$ Japonica subspecies due to genetic causes, or because of the higher tolerance presented in the high emasculation temperatures in IAS 12-9 Formosa.
Table 3. Percentage of grains formed in BRS Pampa and IAS 12-9 Formosa cultivars after emasculation by hyperthermotherapy followed by pollination

\begin{tabular}{|c|c|c|}
\hline \multirow{2}{*}{$\begin{array}{l}\text { Treatments } \\
\text { ( } \mathrm{T} \text { ㅇ C / Time } \mathrm{min} \text { ) }\end{array}$} & \multicolumn{2}{|c|}{$\%$ of Grains Formed } \\
\hline & $\begin{array}{l}\text { BRS } \\
\text { pampa }\end{array}$ & $\begin{array}{l}\text { IAS 12-9 } \\
\text { formosa }\end{array}$ \\
\hline $46^{\circ} \mathrm{C} / 2.5 \mathrm{~min}$ & $23.71 \mathrm{a}$ & $14.96 \mathrm{~b}$ \\
\hline $46^{\circ} \mathrm{C} / 5 \mathrm{~min}$ & $8.25 \mathrm{c}$ & $7.83 \mathrm{c}$ \\
\hline $46^{\circ} \mathrm{C} / 7.5 \mathrm{~min}$ & $0.00 \mathrm{~d}$ & $2.27 \mathrm{~d}$ \\
\hline $46^{\circ} \mathrm{C} / 10 \mathrm{~min}$ & $0.00 \mathrm{~d}$ & $0.00 \mathrm{~d}$ \\
\hline $48^{\circ} \mathrm{C} / 2.5 \mathrm{~min}$ & $0.00 \mathrm{~d}$ & $0.00 \mathrm{~d}$ \\
\hline $48^{\circ} \mathrm{C} / 5 \mathrm{~min}$ & $0.00 \mathrm{~d}$ & $0.00 \mathrm{~d}$ \\
\hline $48^{\circ} \mathrm{C} / 7.5 \mathrm{~min}$ & $0.00 d$ & $0.00 \mathrm{~d}$ \\
\hline $48^{\circ} \mathrm{C} / 10 \mathrm{~min}$ & $0.00 \mathrm{~d}$ & $0.00 \mathrm{~d}$ \\
\hline $50^{\circ} \mathrm{C} / 2.5 \mathrm{~min}$ & $0.00 d$ & $0.00 \mathrm{~d}$ \\
\hline $50^{\circ} \mathrm{C} / 5 \mathrm{~min}$ & $0.00 d$ & $0.00 \mathrm{~d}$ \\
\hline $50^{\circ} \mathrm{C} / 7.5 \mathrm{~min}$ & $0.00 \mathrm{~d}$ & $0.00 \mathrm{~d}$ \\
\hline $50^{\circ} \mathrm{C} / 10 \mathrm{~min}$ & $0.00 \mathrm{~d}$ & $0.00 \mathrm{~d}$ \\
\hline
\end{tabular}

In the emasculation condition of $46^{\circ} \mathrm{C}$ for 5 minutes, both cultivars presented similarity in the percentage of grains formed, and lower than in the previous condition, when comparing Table 3 data to that from Table 2 in emasculation by $4^{\circ} \mathrm{C}$ for 5 minutes. It is observed that the BRS Pampa showed a higher percentage of grains formed in the second year of the experiment, thus occurring artificial hybridization. In this condition, this cultivar had a reduction in the percentage of grains formed $(8.25 \%)$ compared to the emasculation by $46^{\circ} \mathrm{C}$ for 2.5 minutes $(23.71 \%)$, due to the longer emasculation time. However, IAS 12-9 Formosa presented a similar percentage of grains formed in the two years. This is due to the greater tolerance presented by this genotype at high emasculation temperatures.

With the pollination process carried out in the second year, it can be seen that from the temperature of $46^{\circ} \mathrm{C}$ and time of 7.5 minutes until the temperature of $50^{\circ} \mathrm{C}$ and 10 minutes, the female structure of the rice flower was damaged by the high temperatures. This caused infertility of the female gamete, except for IAS 12-9 Formosa at the temperature of $46^{\circ} \mathrm{C}$ for 7.5 minutes. (Table 3 ), which presented a similar percentage of formed grains during the two evaluation years. The occurrence of a possible self-pollination before the emasculation process in the first year of evaluation resulted in a small percentage of grains formed at temperatures of ${ }^{4} 6^{\circ} \mathrm{C}$ for 10 minutes and $48^{\circ} \mathrm{C}$ for 2.5 minutes in both cultivars, as well as for BRS Pampa at a temperature of $46^{\circ} \mathrm{C}$ for 7.5 minutes (Table 2), 
which made the hyperthermotherapeutic emasculation impossible. In the second year, it can be seen that these temperatures cause thermal damage to the female structure, that is, sterility.

The effect of high temperature can cause death of cells and tissues, occurring within minutes or even seconds [15]. With the results of high temperature being a complex function of intensity, duration and temperature variation [16], as well as the stage of development of the plant, with the reproductive phase being the most sensitive [17].

This thermal stress can reduce the number, decrease size and deform the flower organs [18], impair cell division and decrease pollen production [8], promote poor dehiscence of the anthers by the closure of the locules, reducing dispersion of rice pollen grains [11], and cause the deposition of carbohydrates in the pollen grains [19], which may be due to disturbances in sugar metabolism on the tapetum [20]. It also induces early abortion of tapetal cells [21], reducing energy for pollen tube growth, causing sterility of the spikelet. Cell death due to high temperatures is attributed to a catastrophic collapse in its organization due to changes in its structures [22].

High temperatures induce the production of reactive oxygen species, which in high concentrations will result in oxidative damage and, potentially, cell death [23]. With the increase of reactive oxygen species levels, plant growth regulator production and alteration of membrane fluidity can act as factors to trigger transcriptional changes due to high temperatures [24], resulting in the expression of genes coding for the heat shock proteins.

These proteins are known to be an important strategy for adaptation and repair under high temperature stress conditions, helping to maintain the integrity and properties of cell membranes, protecting intracellular proteins from being denatured and preserving their stability [25].

Genotypes of rice tolerant to high temperatures present a greater accumulation of heat shock proteins in the anthers [26]. Quantitative Trait Loci (QTLs) associated with high levels of heat shock proteins in the anthers, spikelets and rice leaf, provide maintenance of grain formation under high temperatures $[27,28]$.
When the results of Table 3 are related to the described discussions, it can be inferred that the conditions of emasculation by hyperthermotherapy that resulted in zero percent of grains formed are due to the stress suffered by the cells, causing their death. On the other hand, in the cases where grains were formed, hybridization or tolerance to stress by the genotype occurred. To verify the occurrence of hybridization, the plants resulting from the $\mathrm{F} 1$ seeds were evaluated in the field by means of a morphological marker (pilosity).

In the comparison between the two methods of emasculation (Table 4), a difference in the percentage and quantity of grains formed is observed. The vacuum suction method presented the best results for these two variables, because the method promotes the removal of the anthers without causing damage to the female structure of the flower. In the other method, the temperature of the emasculation water physically affects the whole rice flower. The amount of grains formed in rice, through emasculation by hyperthermotherapy and vacuum suction, obtaining $16.5 \%$ and $31.5 \%$, respectively [14]. Indicating that vacuum suction provides greater amount of grains formed. Since the emasculation by hyperthermotherapy presents a higher operating efficiency, that is, a greater amount of emasculated panicles at a given time, this difference in grains formed in the hybridization can be easily compensated.

Emasculation by hyperthermotherapy showed higher efficiency, due to the higher percentage of hybrid plants than vacuum suction, being $97.33 \%$ and $88.12 \%$, respectively (Table 4). Emasculation by hyperthermotherapy results in a higher percentage of $\mathrm{F} 1$ hybrid plants, with a suitable temperature for each cultivar [14]. This method provides a higher percentage of hybrid $\mathrm{F} 1$ plants, since it is more stable because it has controlled temperature and time, which promotes greater sterility of the pollen grain. While the suction method has a greater susceptibility to error because there maybe failure in removing all rice flower anthers, leaving some behind and causing self-pollination.

Hyperthermotherapy can be applied in rice breeding programs, since it facilitates the execution, improves the operational performance and allows an increase in the quantity of $F 1$ hybrid seeds obtained, facilitating the selection of genetically superior genotypes. 
Table 4. Percentage and quantity of grains formed in rice using the methods of emasculation by hyperthermotherapy and vacuum suction, and percentage of F1 hybrids

\begin{tabular}{llll}
\hline Emasculation method & Grains formed (\%) & Quantity of grains formed & $\%$ F1 Hybrids \\
\hline Hyperthermotherapy & $23.62 \mathrm{~b}$ & $92 \mathrm{~b}$ & $97.33 \mathrm{a}$ \\
Vacuum suction & $38.56 \mathrm{a}$ & $127 \mathrm{a}$ & $88.12 \mathrm{~b}$ \\
\hline \multicolumn{2}{l}{ The averages followed by the same letter do not differ statistically from each other by the Tukey test at the 5\% probability level. }
\end{tabular}

\section{CONCLUSION}

1. Among all the emasculation by hyperthermotherapy conditions analyzed, the condition that presented the best result to perform the hybridization was a temperature of $46^{\circ} \mathrm{C}$ for a panicle immersion time of 2.5 minutes for both cultivars.

2. The progressive increase in temperature and time decreases the formation of grains to a certain condition in which the total sterilization of rice flowers occurs. The genotypes of the Japonica subspecies have a greater tolerance to this stress.

3. The emasculation by vacuum suction method results in a higher quantity of grains formed, but with a higher percentage of self-fertilization. However, hyperthermotherapy produces a smaller amount of grains, but presents a lower percentage of self-fertilization, thus, being more effective in the artificial rice hybridization process.

\section{COMPETING INTERESTS}

Authors have declared that no competing interests exist.

\section{REFERENCES}

1. Coffman WR, Herrera RM. Rice: hybridization of crop plants. Madison, Wisconsin (USA): American Society of Agronomy. 1980;511-521.

2. Cordeiro ACC. In: Genetic improvement methods of irrigated rice. Boa Vista: Embrapa Roraima. 2008;46.

3. Hedhly, A. Sensitivity of flowering plant gametophytes to temperature fluctuations. Environmental and Experimental Botany, Bornova-İzmir. 2011;74:9-16.

4. Tong L, Yoshida T. Can hot-water emasculation be applied to artificial hybridization of indica - Type Cambodian Rice? Plant Production Science, Nagoya. 2008;11:132-133.
5. Silva F. de AS, Azevedo CAV. de. Principal components analysis in the software assistat-statistical attendance. In: World Congress on Computers in Agriculture, 7, USA: American Society of Agricultural and Biological Engineers; 2013.

6. Nakagawa H, Horie T, Matsui T. Effects of climate change on rice production and adaptive technologies. In Rice Science: Innovations and impact for livelihood. Proceedings of the International Rice Research Conference, Beijing, China, 1619 September 2002 (Eds T.W. Mew, D. S. Brar, S. Peng, D. Dawe \& B. Hardy). 2003; 635-658.

7. Farrell TC, et al. Genotypic variation for cold tolerance during reproductive development in rice: Screening with cold air and cold water. Field Crops Research, Aberdeenshire. 2006;98:178-194.

8. Prasad PVV, et al. Species, ecotype and cultivar differences in spikelet fertility and harvest index of rice in response to high temperature stress. Field Crops Research, Aberdeenshire. 2006;95:398-411.

9. Matsui T, Omasa K, Horie T. The difference in sterility due to high temperatures during the flowering period among japonica-rice varieties. Plant Production Science, Nagoya. 2001;4:9093.

10. Shah F. et al. Impact of high-temperature stress on rice plant and its traits related to tolerance. Journal of Agricultural Science, Belihuloya. 2011;149:545-556.

11. Matsui T, Omasa K. Rice (Oryza sativa L.) cultivars tolerant to high temperature at flowering: anther characteristics. Annals of Botany, Oxford. 2002;89:683-687.

12. Chhabra AK. Emasculation and pollination techniques. Department of Plant Breeding, CCSHAU, Hisar, Haryana, India; 2010.

13. Sha X. Rice artificial hybridization for genetic analysis. Rice Protocols, Methods in Molecular Biology, Springer Science Business Media. 2013;956:Chapter 1: 112. 
14. Yzaguirre AG, Carreres R. Efficiency of different hybridization methods in single crosses of rice for pure line breeding. Spanish Journal of Agricultural Research, Madrid. 2008;6(3):395-400.

15. Hasanuzzaman M, Hossain MA, Fujita M. Physiological and biochemical mechanisms of nitric oxide induced abiotic stress tolerance in plants. American Journal of Plant Physiology, Nova lorque. 2010;5:295-324.

16. Thakur $P$, et al. Cold stress effects on reproductive development in grain crops: An overview. Environmental and Experimental Botany, Bornova-İzmir. 2010; 67:429-443.

17. Prasad PVV, et al. Sensitivity of grain sorghum to high temperature stress during reproductive development. Crop Science, Madison. 2008;48(5):1911-1917.

18. Morrison MJ, Stewart DW. Heat stress during flowering in summer Brassica. Crop Science, Madison. 2002;42:797-803.

19. Jain M. et al. Effects of season-long high temperature growth conditions on sugar-tostarch metabolism in developing microspores of grain sorghum (Sorghum bicolor L. Moench). Planta, Berlin. 2007; 227:67-79.

20. Oliver SN, et al. Cold-induced repression of the rice anther-specific cell wall invertase gene OSINV4 is correlated with sucrose accumulation and pollen sterility. Plant, Cell and Environment, Malden. 2005;28:1534-1551.

21. Parish RW, Phan HA, lacuone S, Li SF. Tapetal development and abiotic stress: A centre of vulnerability. Functional Plant Biology, Hobart. 2012;39:553-559.

22. Howarth CJ. Genetic improvements of tolerance to high temperature. In: Ashraf, M., Harris, P.J.C. (Eds.), Abiotic Stresses: Plant Resistance Through Breeding and Molecular Approaches. Howarth Press Inc., New York; 2005.

23. Apel K, Hirt H. Reactive oxygen species: Metabolism, oxidative stress, and signal transduction. Annual Review of Plant Biology, Palo Alto. 2004;55:373-399.

24. Kotak $S$, et al. Complexity of the heat stress response in plants. Current Opinion in Plant Biology, Hertfordshire. 2007; 10:310-316.

25. Baniwal SK, et al. Heat stress response in plants: A complex game with chaperones and more than twenty heat stress transcription factors. Journal of Biosciences, Bangalore. 2004;29:471-487.

26. Jagadish SVK, et al. Physiological and proteomic approaches to address heat tolerance during anthesis in rice (Oryza sativa L.). Journal of Experimental Botany, Eynsham. 2010;61:143-156.

27. Ye C, et al. Mapping QTL for heat tolerance at flowering stage in rice using SNP markers. Plant Breeding, Malden. 2012;131:33-41.

28. Shi W, et al. Source-sink dynamics and proteomic reprogramming under elevated night temperature and their impact on rice yield and grain quality. New Phytologist. Lancaster. 2013;197:825-837.

(C) 2017 Aguiar et al.; This is an Open Access article distributed under the terms of the Creative Commons Attribution License (http://creativecommons.org/licenses/by/4.0), which permits unrestricted use, distribution, and reproduction in any medium, provided the original work is properly cited.

Peer-review history:

The peer review history for this paper can be accessed here: http://sciencedomain.org/review-history/21784 